\title{
ФОРМУВАННЯ КРЕАТИВНОСТІ ПЕРСОНАЛУ В УПРАВЛІННІ ТАЛАНТАМИ ПІДПРИЕМСТВА
} FORMING OF PERSONNEL CREATIVITY
IN MANAGEMENT OF TALENTS OF THE ENTERPRISE

\author{
Драган Олена Іванівна \\ доктор економічних наук, профресор, \\ Національний університет харчових технологій \\ ORCID: https://orcid.org/0000-0002-7606-2385 \\ Рудова Анастасія Ярославівна \\ здобувачка спеціальності 073 «Менеджмент» \\ освітньо-профресійної програми «Менеджмент персоналу», \\ Навчально-науковий інститут економіки і управління \\ Національного університету харчових технологій \\ ORCID: https://orcid.org/0000-0002-9843-0038

\section{Dragan Olena \\ National University of Food Technology} \\ Rudova Anastasia \\ Educational and Scientific Institute of Economics and Management \\ National University of Food Technology
}

\begin{abstract}
У статті обґрунтовується концепція управління талантами з позиції фрормування креативності персоналу. В управлінні талантами основними процесами є залучення, вирощування та утримання талановитих працівників, що створюють інтелектуальний продукт, інновації та забезпечують комерційний успіх компанії. Для підтримання креативності персоналу в управлінні талантами фрормується креативне середовище завдяки чому забезпечуються потрібні умови для розвитку інтелектуального потенціалу. Узагальнені наукові підходи до трактування поняття «креативність» як здатності, навику, компетентності тощо. Проаналізовані параметри креативності відповідно до наукових праць Дж. Гілфорда та П. Торренсона, визначені спільні та відмінні риси. Обґрунтовані причини, що обмежують розвиток креативності працівників з різних позицій - компанії та талановитого працівника. Узагальнені фрактори, що сприяють формуванню креативності персоналу підприємства. Запропоновані заходи для покращення креативності працівників в управлінні талантами підприємств.

Ключові слова: креативність, управління талантами, креативне середовище, інтелектуальний потенціал, персонал, талановиті працівники, підприємство.
\end{abstract}

В статье обосновывается концепция управления талантами с позиции орормирования креативности персонала. В управление талантами основными процессами является привлечение, выращивание и удержание талантливых работников, создающих интеллектуальный продукт, инновации и обеспечивают коммерческий успех компании. Для поддержания креативности персонала в управлении талантами фрормируется креативная среда благодаря чему обеспечиваются необходимые условия для развития интеллектуального потенциала. Обобщенные научные подходы к трактовке понятия «креативность» как способности, навыка, компетентности и тому подобное. Проанализированы параметры креативности в соответствии с научными работами Дж. Гилфорда и П. Торренсона, определенные общие и отличительные черты. Обоснованы причины, ограничивающие развитие креативности работников с разных позиций - компании и талантливого работника. Обобщенные фракторы, способствующие формированию креативности персонала предприятия. Предложенные меры по улучшению креативности работников в управлении талантами предприятий.

Ключевые слова: креативность, управления талантами, креативная среда, интеллектуальный потенциал, персонал, талантливые работники, предприятие.

Actuality of conception generalization of talents management from the position of forming of personnel creativity is grounded in the article. In talents management the basic processes are recruitment, keeping and supporting of talented 
workers that create intellectual product, innovations and provide commercial success of the company. For keeping of personnel creativity in talents management creative environment is formed due to the necessary terms for development of work are provided. Scientific approaches to the interpretation of concept of "creativity" as ability, skill, competence, personality property, style of thinking, activity and sensitivity, creative orientation and others like that are generalized. Creativity parameters in accordance with researches of J. Guilford and P. Torrance, similar and different characteristics are certain. Reasonable reasons that limit creative potential of workers from different positions - of the company and worker are analyzed. From the position of company: unsatisfactory social and psychological climate among personnel, worsening of labour terms, job decline, observance of hard regulation, critic evaluation, bureaucracy and others like that are given. From position of talented worker: absence of self-motivation and unsatisfactory psychological state, uncomfortable workplaces, insufficient level of the development of competence and professional competences, absence of time-management skills and self-management, aimed at individual result and reward and others like that. The factors that assist forming of personnel creativity of the enterprise are generalized. Events for the improvement of workers creativity in talents management by the enterprises are offered. Creative personnel manager must find approaches to any worker, beginning from his period of adaptation and continuing his career advancement, when he will become the talent is described. There is a recurrence of continuous processes: forming the terms for the development of personnel creativity - of talents supporting that create innovations, give ideas - providing the economic results - resources obtaining of keeping the functioning of creative environment in the management of talents organization.

Keywords: creativity, talents management, creative environment, staff, intellectual potential, talented workers, enterprise.

Постановка проблеми. Практика відомих зарубіжних компаній свідчить, що на шляху досягнення ними економічної успішності на перший план виходять чинники, пов'язані із зростанням інтелектуального капіталу. Водночас новим стратегічним підходом до управління інтелектуальним капіталом стало управління талантами, яке залучає ефрективних співробітників, впроваджує програми розвитку, просування та утримання талантів. Першочерговим завданням управління талантами $€$ формування середовища для забезпечення умов розвитку креативності персоналу та реалізації нових ідей.

Аналіз останніх досліджень і публікацій. Теоретико-прикладні питання управління талантами в діяльності компаній досліджені у працях авторів, таких як: Е. Майклз, Х. Хэндфилд-Джонс і Е. Екселрод [1],
М. Есрфррон і М. Орт [2], Н. Кузнєцов [3], В. Пікалов [4] та інших. Водночас розгляд управління талантами з позиції забезпечення умов розвитку креативності талановитих працівників $€$ недостатньо дослідженим питанням у сорері менеджменту персоналу.

Постановка завдання. Метою статті $€$ : 1) розгляд концепції управління талантами 3 позиції забезпечення креативності; 2) визначення аспектів формування креативності персоналу в управлінні талантами підприємства.

Виклад основного матеріалу. Управління талантами визначає пріоритети успішного бізнесу компаній завдяки залученню, вирощуванню та утриманню талановитих працівників, що створюють інтелектуальний продукт та інновації. Концепція управління талантами на підприємстві наведена на рис. 1.

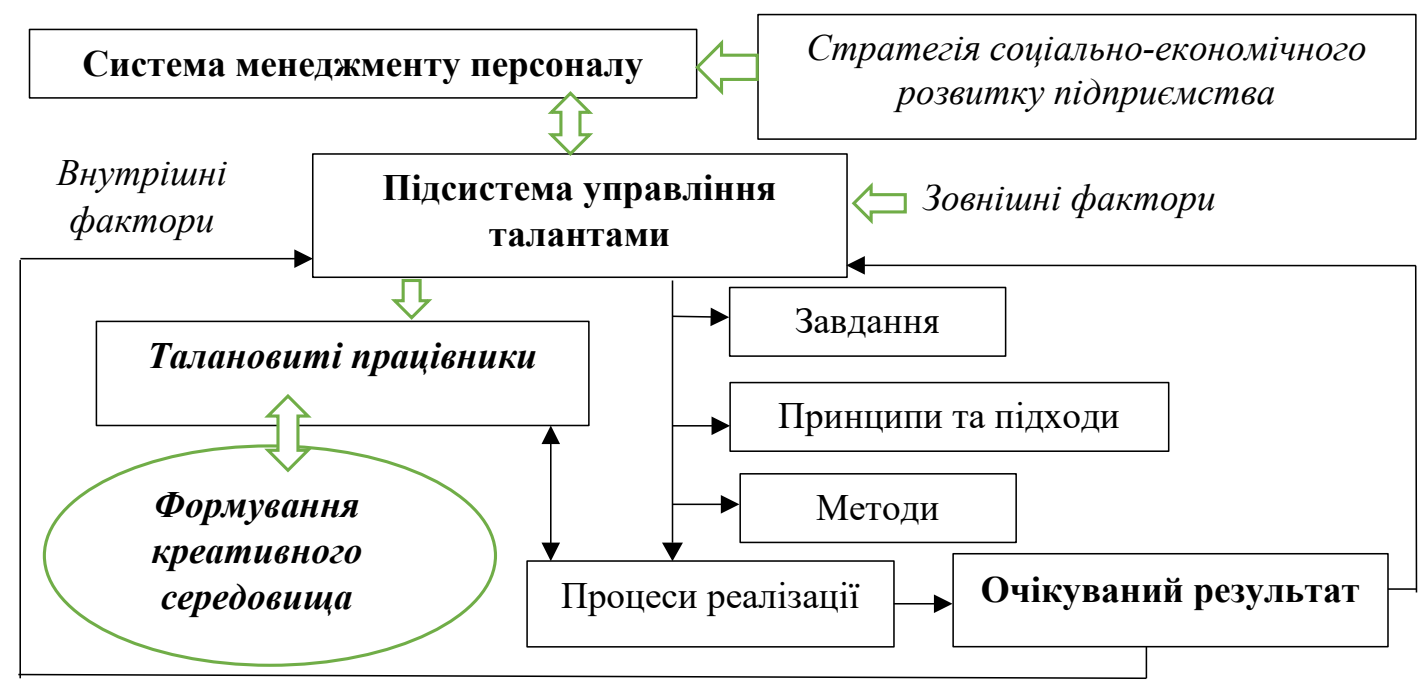

Рис. 1. Системний підхід до управління талантами підприємства Джерело: складено авторами 
Для підтримання креативності персоналу в управлінні талантами формується креативне середовище завдяки чому забезпечуються потрібні умови.

Креативність (лат. «сreation» - створення; англ. «creativity» - творчість) - $€$ компетенцією, здатністю особи створити нову ідею, віднайти незвичайне вирішення, ігнорувати традиційну схему мислення [8].

Цей термін з'явився у роботах Д. Сімпсона (1922 р.), як здатність особи відмовитись від стереотипного мислення. Узагальнення підходів до сутності поняття «креативність» наведено у табл. 1.

Вивчаючи «креативність» необхідно звернути увагу на її основні параметри, які були виділені у своїх напрацюваннях Дж. Гілсрордом та П. Торренсоном.

Спираючись на наведені параметри креативності, було визначено, що креативній особистості притаманні такі риси:
- швидкість мислення, яке характеризується швидким пошуком асоціацій, швидкістю мовлення в рамках заданої теми;

- гнучкість;

- проникливість, яка допомагає віднаходити вузькі місця у великих питаннях, об'єктивне оцінювання;

- індивідуальність, самовираження, бажання бути схожим на всіх;

- толерантність, стриманість;

- цікавість та схильність до сумніву;

- готовність йти на ризик, незалежність думки та інші.

Даний перелік $€$ набагато ширший і $є$ коригованим, оскільки це все також залежить від багатьох фракторів самої особистості та iï навколишнього середовища. Всі ці риси можуть як розвиватись, так і подавлятись суспільством. У таблиці 3 наведено причини, що обмежують розвиток креативності талановитих працівників на підприємстві.

Таблиця 1

Характеристика сутності поняття «креативність»

\begin{tabular}{|c|c|c|}
\hline Автор & Ознака & Характеристика «креативності як...» \\
\hline Дж. Гілорорд & $\begin{array}{l}\text { Пізнавальна } \\
\text { здатність }\end{array}$ & $\begin{array}{l}\text { - пізнавальної творчої здатності адаптувати поведінку } \\
\text { до змінних умов за допомогою методу спроб та помилок. }\end{array}$ \\
\hline Едвард де Боно & Навик & - як навику, який можна опанувати або розвити. \\
\hline $\begin{array}{l}\text { Тереза М. } \\
\text { Амабель }\end{array}$ & Компетентність & $\begin{array}{l}\text { - взаємодії компонентів, таких як: компетентність, } \\
\text { уміння творчо мислити та мотивування. }\end{array}$ \\
\hline О. Халіфраєва & $\begin{array}{l}\text { Інтегральна } \\
\text { властивість } \\
\text { особистості }\end{array}$ & $\begin{array}{l}\text { - інтегральна властивість особистості, що складається } \\
\text { із різноманіття способів вирішення життєвих проблем } \\
\text { та проявляється в індивідуально-психологічних рисах, } \\
\text { які визначають активність особи у суспільстві. }\end{array}$ \\
\hline Р. Стернберг & \multirow{3}{*}{$\begin{array}{l}\text { Здатність, } \\
\text { готовність }\end{array}$} & $\begin{array}{l}\text { - здатності особи йти на розумний риск, бути готовою } \\
\text { долати перешкоди, бути внутрішньо мотивованою, бути } \\
\text { готовим протистояти інакодумцям, а прояв креативності } \\
\text { неможливий без творчого середовища. }\end{array}$ \\
\hline Д. Сімпсон & & $\begin{array}{l}\text { - здатності особи відмовитись від стереотипного } \\
\text { способу мислення. }\end{array}$ \\
\hline Е. Фромм & & $\begin{array}{l}\text { - здатності дивуватись, відшукати рішення у } \\
\text { незвичайній ситуації, спрямованість до нового, вміти } \\
\text { глибоко усвідомлювати особистий досвід. }\end{array}$ \\
\hline Ч. Лендрі & Стиль мислення & $\begin{array}{l}\text { - відмінний стиль мислення, який є більш схильним } \\
\text { до запитань, а ніж до критики. }\end{array}$ \\
\hline П. Торренс & $\begin{array}{l}\text { Чутливість } \\
\text { особи }\end{array}$ & $\begin{array}{l}\text { - підвищена чутливість особи до вирішення наявних } \\
\text { проблем, до дефріциту або розбіжностей знань, } \\
\text { до пошуку рішень на основі запропонованих ідей. }\end{array}$ \\
\hline Є. Яковлева & $\begin{array}{c}\text { Особистісна } \\
\text { характеристика }\end{array}$ & $\begin{array}{l}\text { - особистісна характеристика особи, яка проявляється } \\
\text { в реалізації її власної індивідуальності. }\end{array}$ \\
\hline Я.О. Пономарьов & $\begin{array}{c}\text { Активність } \\
\text { і сенситивність }\end{array}$ & $\begin{array}{l}\text { - інтелектуальна активність та сенситивність } \\
\text { до продуктів власної діяльності. }\end{array}$ \\
\hline А. Маслоу & $\begin{array}{c}\text { Творча } \\
\text { спрямованість }\end{array}$ & $\begin{array}{l}\text { - творча спрямованість яка властива всім від народження, } \\
\text { але втрачається більшою частиною під впливом таких } \\
\text { фракторів, як виховання, освіта та соціальна практика. }\end{array}$ \\
\hline
\end{tabular}

Джерело: складено авторами на основі [6; 7; 10; 13; 14; 15] 
Таблиця 2

Параметри креативності за Дж. Гілфордом та П. Торренсоном

\begin{tabular}{|c|c|c|c|}
\hline \multicolumn{2}{|r|}{ Дж. Гілфрорд } & \multicolumn{2}{|r|}{ П. Торренс } \\
\hline Параметри & Характеристика & Параметри & Характеристика \\
\hline Оригінальність & $\begin{array}{l}\text { Ознака особистості, що робить } \\
\text { її неповторною, відрізняє } \\
\text { від інших, нестандартність } \\
\text { мислення та дій. }\end{array}$ & Продуктивність & $\begin{array}{l}\text { Здатність генерувати безліч } \\
\text { ідей }\end{array}$ \\
\hline $\begin{array}{l}\text { Семантична } \\
\text { гнучкість }\end{array}$ & $\begin{array}{l}\text { Здатність бачити існуючий } \\
\text { об'єкт } 3 \text { нового боку, пошук } \\
\text { нового використання вже } \\
\text { існуючого об'єкту. }\end{array}$ & Гнучкість & $\begin{array}{l}\text { Здатність пропонувати різні } \\
\text { ідеї, можливість переходити } \\
\text { від одного питання до іншого. }\end{array}$ \\
\hline $\begin{array}{c}\text { Образна } \\
\text { адаптивна } \\
\text { гнучкість }\end{array}$ & $\begin{array}{l}\text { Здатність бачити нові ознаки } \\
\text { в існуючому об'єкті. }\end{array}$ & Оригінальність & $\begin{array}{l}\text { Здатність висувати ідеї, які } \\
\text { відрізняються від існуючих, } \\
\text { стандартних штампів. }\end{array}$ \\
\hline $\begin{array}{l}\text { Семантична } \\
\text { спонтанна } \\
\text { гнучкість }\end{array}$ & $\begin{array}{l}\text { Здатність створювати } \\
\text { різні ідеї в невизначених } \\
\text { ситуаціях. }\end{array}$ & Деталізація & $\begin{array}{l}\text { Реалізація ідеї від її } \\
\text { зародження. }\end{array}$ \\
\hline
\end{tabular}

Джерело: складено авторами на основі [6; 7]

Причини, що обмежують розвиток креативності працівників

Таблиця 3

\begin{tabular}{|l|l|}
\hline \multicolumn{1}{|c|}{ Причини з позиції компанії } & \multicolumn{1}{|c|}{ Причини з позиції працівника } \\
\hline $\begin{array}{l}\text { Незадовільний соціально-психологічний } \\
\text { клімат в колективі }\end{array}$ & $\begin{array}{l}\text { Відсутність самомотивації саморозвитку } \\
\text { та незадовільний психологічний стан. }\end{array}$ \\
\hline Погіршення умов праці. & Некомфортні робочі місця. \\
\hline Зниження оцінки результатів праці. & $\begin{array}{l}\text { Недостатній рівень профресійних та творчих } \\
\text { здібностей. }\end{array}$ \\
\hline $\begin{array}{l}\text { Критика, дотримання жорсткого регламенту, } \\
\text { бюрократія. }\end{array}$ & $\begin{array}{l}\text { Відсутність навиків тайм-менеджменту } \\
\text { і самоменеджменту. }\end{array}$ \\
\hline $\begin{array}{l}\text { Відсутність мотиваційних програм } \\
\text { та ігнорування досягнень працівників. }\end{array}$ & $\begin{array}{l}\text { Недостатній рівень розвитку компетентності } \\
\text { та професійних компетенцій. }\end{array}$ \\
\hline Відсутність командної співпраці, тимбілдингу. & $\begin{array}{l}\text { Націленість на індивідуальний результат } \\
\text { та винагороду, складності з гуртованістю. }\end{array}$ \\
\hline $\begin{array}{l}\text { Фінансові проблеми, скорочення витрат } \\
\text { на утримання та розвиток персоналу, } \\
\text { режим економії, скорочення ресурсів. }\end{array}$ & $\begin{array}{l}\text { Незадовільний рівень мотивації та } \\
\text { стимулювання інтелектуальної праці. }\end{array}$ \\
\hline
\end{tabular}

Джерело: складено авторами

На рисунку 2 умовно зображено фрази креативного процесу, оскільки у реальному житті не спостерігається чітке розмежовування фраз між собою.

Наведені фрази характеризуються наступним чином:

1. Зародження - спроба генерувати нові ідеї.

2. Пожвавлення - інтерес та готовність до появи нових, незвичних ідей.

3. Пік - легке та швидке генерування оригінальних, незвичайних ідей, стійкий інтерес до іiї реалізації.

4. Спад - зменшення рівня інтересу до праці, зниження рівня мотивації, ідеї стають спонтанними, є доречними та недоречними.

5. Депресія - відсутність підтримки, страх критики виражених ідей, невдоволення умо- вами праці, що спричиняє появу шаблонних ідей, небажання звертатись до креативного мислення.

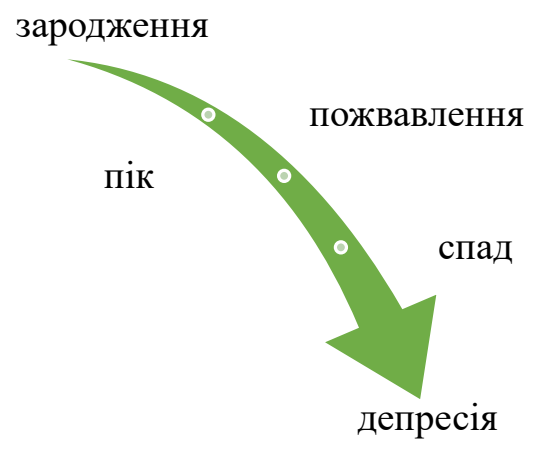

Рис. 2. Фази креативного процесу Джерело: [9; 14] 
Мета фрормування креативного середовища підприємства - підтримання таланту та максимальне сприяння розкриттю інтелектуального потенціалу працівників. Креативне середовище підприємства розвиває існуючий інтелектуальний потенціал, підтримує потребу в посиленні самопізнання, саморозвитку, самовдосконалення, націлює на застосування нових знань, ідей, навичків та умінь в професійній діяльності.

3 точки зору управління талантами, креативність $€$ процесом створення нових та оригінальних підходів до управління працівниками та прийняттям незвичайних творчих рішень. Креативний менеджер 3 персоналу повинен знайти підхід до будь-якого працівника, починаючи з його періоду адаптації та продовжуючи його кар'єрним просуванням, коли він стане талантом. Переважна більшість підприємств приділяють достатньо уваги талановитим працівникам для того, щоб вони не покидали компанію після стажування, а продовжували працювати та ставали частиною однієї команди однодумців.

На таких підприємствах зустріч нового працівника починають із створення папкиспівробітника, дарують welcome-book або welcome-box, обирають найбільш підходящий вид адаптації. Деякі менеджери з персоналу, за допомогою певних відділів, починають диджиталізувати старі ідеї, перетворюючи на нові. Так, IT-компанія «OSA Hybrid Platform» перетворила звичний всім welcome-book (книгу співробітника) у чат-бот [16]. Новий працівник 3 легкістю зможе дізнатися про правила роботи в компанії та детально розібратися із тим, де взяти заяву на відпустку. Таким чином, креативні менеджери 3 персо- налу можуть працювати із будь-якими категоріями працівників, підтримуючи їх інтерес та розвиваючи їх, оскільки існує безліч сорер для прояву нових ідей.

Для того, щоб працівники розвивали свою креативність, цьому мають сприяти срактори, приклад яких наведено в таблиці 4.

Для покращення креативності працівників в управлінні талантами підприємств потрібно враховувати деякі аспекти [5]:

1. Створення гнучкого робочого місця можливо за межами офpicy, яке позитивно впливає на креативну діяльність працівників.

2. Схвалення успіхів працівників для створення невимушеної та відкритої атмоссрери, в якій усі діляться успіхами, отримують похвалу і цінну пораду.

3. Перспектива для створення більш креативних результатів за рахунок отримання есрективних прикладів від успіхів інших співробітників команди.

4. Демонстрація вирішення проблем з різних сторін за рахунок застосування різних цікавих думок, поглядів працівників різних відділів та сорер профресійної діяльності у компанії.

5. Побудова довірливих відносин на підставі чесності, прозорості та відкритості між працівниками компанії.

6. Конструктивний зворотній зв'язок між працівниками та керівництвом для розв'язання складних задач або питань, який допомагає та націлює співробітників розвиватися далі і вказує на вірні рішення.

7. Заохочення, постійна мотивація і стимулювання командної роботи між працівниками для комплексного вирішення питань і проблем.

8. Цінність і умотивованість кожного співробітника. Оскільки кожна людина є ком-

Фактори, що сприяють формуванню креативності персоналу підприємства

Таблиця 4

\begin{tabular}{|c|l|l|}
\hline Фактори & \multicolumn{1}{|c|}{ Характеристика } & \multicolumn{1}{|c|}{ Сутність поняття } \\
\hline Енергійність & $\begin{array}{l}\text { Наявна у креативних працівників, які } \\
\text { здатні генерувати ідеї та займаються } \\
\text { творчою діяльність у компанії. }\end{array}$ & $\begin{array}{l}\text { Енергія, яка потрібна для виконання } \\
\text { завдання. Енергія також може } \\
\text { виступати натхненням. }\end{array}$ \\
\hline Реальність & Реалізація ідей у житті & $\begin{array}{l}\text { Пошук шляхів втілення, застосування } \\
\text { конкретної ідеї в реальне життя }\end{array}$ \\
\hline Свіжість & $\begin{array}{l}\text { Організація нових фракторів } \\
\text { та стимулів, зміни професійного } \\
\text { житя, що сприятиме виникненню } \\
\text { нових, незвичайних думок }\end{array}$ & $\begin{array}{l}\text { Пошук нового, для створення нових } \\
\text { ідей, які є неординарними в цій сфері } \\
\text { і які неможливо буде скопіювати } \\
\text { компаніям-конкурентам }\end{array}$ \\
\hline $\begin{array}{c}\text { Сміливість } \\
\text { та хоробрість }\end{array}$ & Споріднено із креативністю & $\begin{array}{l}\text { Сміливість для прийняти рішення та } \\
\text { відповідальність за реалізацію вжиття. }\end{array}$ \\
\hline Теплиця & Середовище для «вирощування» ідейй & $\begin{array}{l}\text { Захист ідей під час їхньго } \\
\text { «вирощування» }\end{array}$ \\
\hline
\end{tabular}


Управління талантами

Креативне середовище

Очікуваний результат

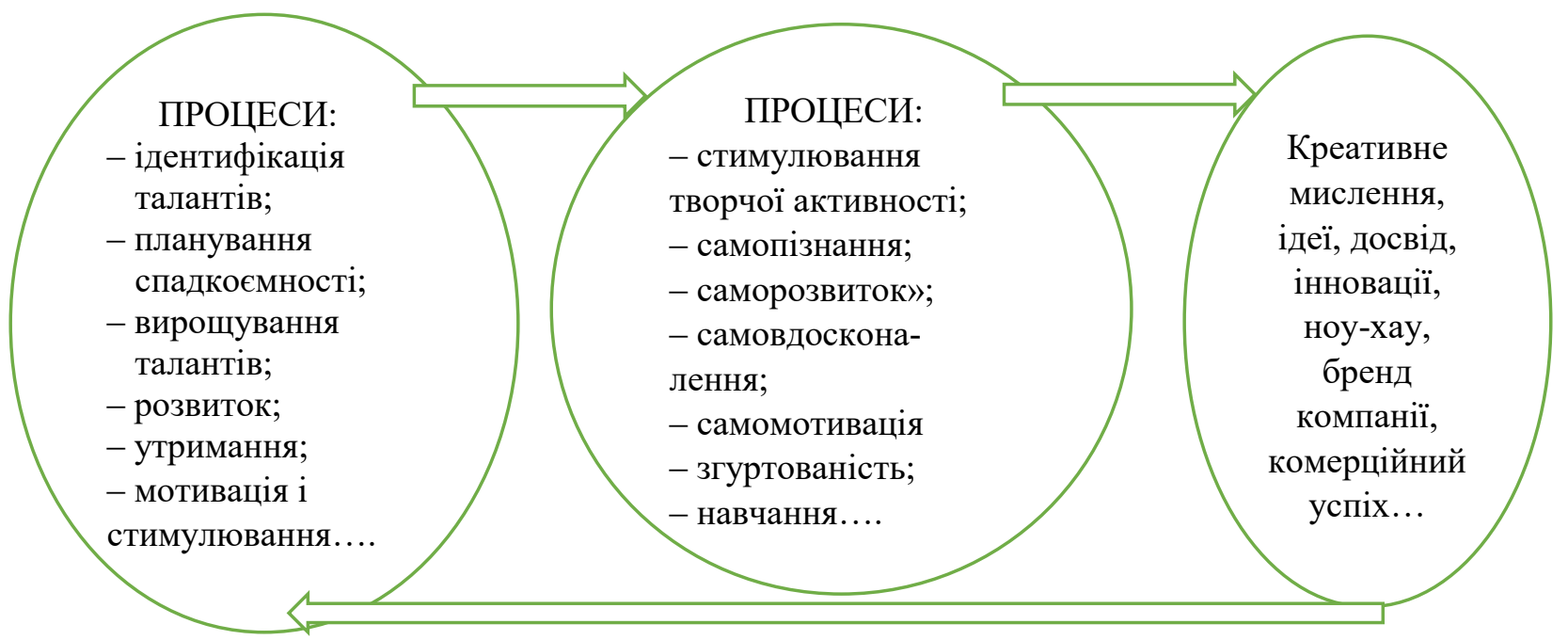

Рис. 3. Взаємозв'язок процесів при формуванні креативності персоналу в управлінні талантами підприємства

Джерело: складено авторами

петентною в окремому колі питань і може надати пораду, допомогу або запропонувати нестандартне вирішення будь-якого питання.

9. Безперервне навчання працівників дозволяє отримувати нову інформацію, знання і сприяє покращенню показників своєї діяльності.

Процеси фформування креативності персоналу в управлінні талантами підприємства наведені на рис. 3.

Висновки. Управління талантами підприємства, націлене на залучення, вирощування, розвиток та утримання талантів. Без розвитку креативності, творчості, яке забезпечує зростання інтелектуального потенціалу, це неможливо. Тому, забезпечується циклічність безперервних процесів: формування умов для розвитку креативності персоналу вирощування талантів, що створюють інновації, реалізують ідеї - отримання комерційних результатів - вкладання ресурсів у підтримання фрункціонування креативного середовища в управлінні талантами організації. Отже, основним інструментом управління талантами стає орормування креативності для максимізації творчих здібностей персоналу, зростання інтелектуального капіталу 3 метою отримання очікуваних високих економічних результатів діяльності підприємства.

\section{СПИСОК ВИКОРИСТАНИХ ДЖЕРЕЛ:}

1. Майклз Э., Хэндфилд-Джонс Х., Экселрод Э. Война за таланты / пер. с англ. Ю.Е. Корнилович. Москва : Манн, Иванов и Фербер, 2012. 280 с.

2. Эфрфрон М., Орт М. Управление талантами : краткий курс. Москва : Азбука Бизнес, Азбука-Атткус, 2014. 224 с.

3. Кузнецова Н.Б. Концепція управління талантами в системі менеджменту знань. Соціально-трудові відносини: теорія та практика : зб. наук. праць. Київ : КНЕУ, 2014. № 2(8). С. 181-187.

4. Пікалов В.Л. Щодо проблем управління талановитими працівниками суб'єктів господарської діяльності. Академічний огляд. 2014. № 1. С. 116-120.

5. 29 tips be award-winning companies on "How to increase creativity in the workplace". URL: https://filestage.io/ blog/29-tips-award-winning-companies-increase-creativity-workplace/ (дата звернення: 15.08.2021).

6. Guilford J. P. The Nature of Human Intelligence. N.Y., 1967. 583 p.

7. Torrance E. P. The Search for Satori and Creativity. Buffalo N. Y. : Creative Education Foundation, 1979.386 p.

8. Башук Т.О., Хижняк М.О. Стимулювання та розвиток креативності персоналу. Маркетинг і менеджмент інновацій. 2013. № 1. С. 150-160.

9. Брич В.Я., Корман М.М. Креативний менеджмент : підручник. Тернопіль : ТНЕУ, 2018. 220 с.

10.Вітвіцька О.В., Підвальна О.Г. Креативний менеджмент в діяльності підприємства. URL: http://www.rusnauka.com/34-NIEK-2010/Economics/ 
11.Дімітрова-Бурлаєнко С.Д. Дефрініції понять «творчість» $\mathrm{i}$ «креативність» у сучасному науковому дискурсі. Педагогічні науки. 2017. Випуск 135. С. 82-89.

12. Креативність. Словник.иа портал української мови та культури. URL: https://slovnyk.ua/index.php? swrd=креативність

13. Майстер-клас Едварда де Боно «Курс креативного мислення в менеджменті. URL: http://www.management.com.ua/events/bono.html

14. Мала Н.Т. Креативність як складова ефективного управління. Гілея: науковий вісник. 2011. С. 18-23.

15. Пономарев Я.А. Психология творчества и педагогика. Москва : Издательство Наука, 1976. 304 с.

16. Сайко Д. Онбординг: навіщо потрібна адаптація працівників? 2020. URL: https://joffer.com.ua/tpost/ d2cum2ezzn-onbording-navscho-potrbna-adaptatsya-pra

\section{REFERENCES:}

1. Michaels E., Handfield-Jones H., Excelrod E. (2012) War for Talent / transl. from English. Yu.E. Kornilovich. Moscow: Mann, Ivanov and Ferber, $280 \mathrm{p}$.

2. Effron M., Orth M. (2014) Talent management: a short course. Moscow: Azbuka Business, Azbuka-Atticus, 224 p.

3. Kuznetsova N.B. (2014) Kontseptsiya upravlinnya talantamy v systemi menedzhmentu znan [The concept of talent management in the knowledge management system]. Sotsial'no-trudovi vidnosyny: teoriya ta praktyka, 2(8), 181-187.

4. Pikalov V.L. (2014) Shchodo problem upravlinnya talanovytymy pratsivnykamy sub"yektiv hospodars'koyi diyal'nosti [Regarding the problems of managing talented employees of economic entities]. Akademichnyy ohlyad, $1,116-120$.

5. 29 tips be award-winning companies on "How to increase creativity in the workplace". Available at: https://filestage.io/blog/29-tips-award-winning-companies-increase-creativity-workplace/

6. Guilford J.P. (1967) The Nature of Human Intelligence. N.Y., 583 p.

7. Torrance E.P. (1979) The Search for Satori and Creativity. Buffalo, N.Y.: Creative Education Foundation, 386 p.

8. Bashuk T.O., Khyzhnyak M.O. (2013) Stymulyuvannya ta rozvytok kreatyvnosti personalu [Stimulation and development of staff creativity]. Marketynh i menedzhment innovatsiy, 1, 150-160.

9. Brych V.YA., Korman M.M. (2018) Kreatyvnyy menedzhment [Creative management]: pidruchnyk. Ternopil: TNEU, $220 \mathrm{~s}$.

10. Vitvitska OV, Pidvalna OG Creative management in the enterprise. Available at: http://www.rusnauka.com/ 34-NIEK-2010/Economics/

11. Dimitrova-Burlayenko S.D. (2017) Definitsiyi ponyat' «tvorchist'» i «kreatyvnist'» u suchasnomu naukovomu dyskursi [Definitions of "creativity" and "creativity" in modern scientific discourse]. Pedahohichni nauky, 135, 82-89.

12. Creativity. Slovnyk.ua portal of Ukrainian language and culture. Available at: https://slovnyk.ua/index.php? swrd=creativity

13. Edward de Bono master class "Creative thinking course in management. Available at: http://www.management.com.ua/events/bono.html

14. Mala N. (2011) Creativity as a component of effective management. Gilea: scientific bulletin, pp. 18-23.

15. Ponomarev YA.A. (1976) Psykholohyya tvorchestva y pedahohyka. Moskva: Yzdatel'stvo Nauka, 304 p.

16. Sayko D. (2020) Onbordynh: navishcho potribna adaptatsiya pratsivnykiv? Available at: https://joffer.com.ua/ tpost/d2cum2ezzn-onbording-navscho-potrbna-adaptatsya-pra 